\title{
Formal Training of IT Managers in Germany: Research Based On Job Advertisements
}

\author{
Bjarne Erik Roscher \\ ${ }^{1}$ Department of Economics and Business Administration, University of Latvia, Riga, Latvia
}

\begin{abstract}
Companies are more and more dependent on information technology (IT) and the buzzword digitization is present everywhere. Some companies are inventing new business models based on disruptive innovation supported by information technology. Others adapt these business models as followers. All these new business processes and underlying information technology need to be managed, serviced and supported by IT organizations to ensure business continuity and successful business transformation. The head of the IT Organisation needs a variety of training, skills and competences to be able to effectively support business processes. In the current research, job advertisements have been analysed to investigate what competences in form of formal training companies are looking for, when they are hiring IT Managers and Chief Information Officers (CIO). The findings indicate that HR departments might require the wrong field of study from applicants. Findings suggest that most studies are not generalistic enough to cover the diverse requirements and tasks of an IT Organization. Mostly this lack of diversified knowledge is compensated by the request of the employer towards the applicant to have several years of service in the IT domain.
\end{abstract}

Keywords: Chief Information Officer, IT Organization, recruiting, education, Job advertisements.

\section{Introduction: CIO Role, Tasks and Competencies}

Sinnott et. al. defined 1981 the role of the chief information officer (CIO) as the "senior executive responsible for establishing corporate information policy, standards, and management control over all corporate information resources". (Synnott and Gruber 1981)

This job title has been adapted also in other countries, among these Germany. Yet, this research indicates that this is mainly the case in larger enterprises while small and mid-sized enterprises (SME) call their IT executives "IT Leiter", "IT Manager" or "IT Abteilungsleiter". Yet, also US based research show that other job titles like "IT director", "SVP/VP IT" and "IT manager" are widely used (Tallon 2014). 


\section{i[ERBMF}

Many studies have shown that the role of a CIO is essential for an organization:

A CIO can positively influence the company performance not only by fostering the IT efficiency, which means lowering cost and by this increase the profit but increase the IT effectivity through improved IT use (Durst 2008).

Measures to drive IT efficiency are introducing tailored internal IT management systems (Schweda and Schmidt 2014), efficient IT service management (ITSM) frameworks (Marrone and Kolbe 2011) and the right organizational setup (Hodgkinson 1992). An efficient budgeting and controlling process which ensures that investments in technology deliver the planned results (Chan et al. 2006) is essential. Measures to improve IT effectivity are underpinning business processes with appropriate information technology (Tallon 2014).

But ultimately a CIOs main task is to ensure Business- IT- Alignment (BITA). This results in strategic information technology initiatives driving business performance (Peppard 2010).

To deliver this, training and education is needed. This research investigates, if requirements towards applicants, in job advertisements, regarding their field of study is, fulfilling the requirements of the role of a CIO or IT Manager.

\section{Methodology of the empirical research}

To gain deeper insights into the CIO and IT Manager role, its tasks and scope, Job advertisements in Germany have been analyzed.

\subsection{Selection of Sources}

The search of the job market regarding open positions of CIOs and IT managers has been carried out by searching HR online portals and social networks which offer job advertisements. After searching on different portals, it was found that most job openings are present in several places. This led to the decision to focus on the following portals for final information gathering: www.LinkedIn.com and www.Indeed.com. A total of 87 job ads have been collected manually from 2 platforms (indeed.com and linkedin.com) on one single day (18.2.2020). All records have been copied and archived for further research.

The ads represent all job openings in Germany on a single day from these two platforms. Scope has been the upper IT management and digitization management jobs.

\subsection{Data cleansing}

Process of data cleansing: After manual proofreading, 4 records have been removed for the analysis as their job title did not correspond with the content or had been outdated or not complete. Additional four Datasets have been removed as the job title was Chief Digital Officer (CDO) and the tasks of these positions differed too much from those of IT managers and CIOs. The remaining $\mathrm{N}=79$ records have been analyzed with a structured content analysis. 


\section{i[C를}

\subsection{Codes}

Codes have been used to cluster the information of all job advertisements:

- "Company"

- "Job title"

- "Job information"

- "Tasks": According to Krcmar [9] the tasks for organizations can be clustered into 4 main areas

a) IT Management function based on the resource employee

b) Management of information based on the resource information

c) Management of information systems based on the resource IT application

d) Management of information- and communication technology based on the resource Infrastructure

This structure was also used for this further classification of qualification needs regarding lectures in different fields of study.

- "Profile"

a) formal training

- Type of education

- $1^{\text {st }}$ field of study/education

- $2^{\text {nd }}$ field of study/education

- $3^{\text {rd }}$ field of study/education

- alternative study/education

b) Competences

c) Skills

The Codes used for this research was of statistical nature as "Job title" and content wise "Profile- formal training".

\subsection{Coding rules}

Some codes on the first level as Tasks, Profile Company info, Job information and Benefits/Company offers have partly been used several time per Job advertisements. This was used to analyze the structure of the records.

Others like Job title, Company name, Location only once, as well as subcategories of Task and Profile have only been used once per ad.

\subsection{Verification of Codes for Tasks}

Krcmar developed based on findings of Wollnik (Wollnik 1988) and Szyperski und Winand (Szyperski and Winand 1989) and his own research (Krcmar 1991) a 3 Level model of Information management by adding a Management Role of IT Organisation.

Previous own research (Roscher and Brink 2020) was used the Model of Krcmar by adding additional tasks as new clusters:

These Clusters contain based on analisis of $\mathrm{N}=79$ Job ads following tasks:

a) Finance \& Administration: Supplier Coordination / IT Sourcing and Budgeting 


\section{i[ERBMF}

b) Innovation \& Architecture: IT Architecture, IT Trends \& Technology

c) Business- IT- Allignment: Project Management, Consulting/Demand Management on Management level, Cooperation with others, IT effectivity

\section{Results and Conclusion}

\subsection{General findings about empirical research on job advertisements}

The Records could be clustered into 4 Job title groups: Chief Information Officer / CIO (8), Chief, IT Leiter (37), IT Manager (23), other IT Manager Job titles (13). Some of the job titles have been combinations of the above which resulted in double counting.

The job advertisements have been published by organizations in the following regions of Germany: Baden Württemberg (19), Bayern (11), Berlin (4), Brandenburg (1), Bremen (1), Hamburg (3), Hessen (8), Mecklenburg- Vorpommern (0), Niedersachsen (5), NordrheinWestfahlen (12), Rheinland Pfalz (5), Saarland (0), Sachsen (4), Sachsen Anhalt (3), Schleswig

Hollstein (3), Thüringen (1).

\subsection{Analysis of job advertisements regarding required field of study and education.}

Within the continuous text of the „Profile "category and its subcategory „formal training "the information was clusted as described above. 60 employers requested a successfully completed academic study, yet opened up for an IT professional education in 23 cases. 9 employers requested a professional education as the preferred background, yet opening up of an academic study in 2 cases.

8 employers did not ask for a formal training within the job advertisements but supplemented the missing requirement by experience in some cases.

The following fields of study have been requested by the employers. (Frequency of total mentioning's in brackets): Informatics (41) whereof 26 as a first choice, Business Informatics (38) whereof 18 as a first choice, IT (17) all first choice, Medical Informatics (7), Industrial Engineers (2), Business Administration (2).

Data Cleansing: As a field of Study „IT “does not exist explicitly and is not specific it has not been considered for further research. Also the study field medical informatics was not considered, as it was only required as an alternative to other common studies by hospitals. It is specific to a field of business and not representative for other businesses. 


\subsection{Mapping of study content to Tasks of an IT Organization}

In order to validate, if the education requirement stated in the profile section of job advertisements fits to the role of a CIO or IT Manager, the tasks, both defined by Krcmar and defined by own research (Roscher and Brink 2020), have been used to analyze the content of 4 different fields of studies frequently mentioned by the employers.

As source of information about the content of lectures in the fields of study „Informatics “, „Business informatics “, „Industrial engineering “and „Business administration “the public available website of a German private university of applied sciences was used (FOM Hochschule für Oekonomie).

The lectures where mapped to the tasks of an IT organisation manually for each field of study.

The results are presented in fig. 1.

Tasks of an IT Organization covered by lectures in IT Management relevant studies ${ }^{1}$

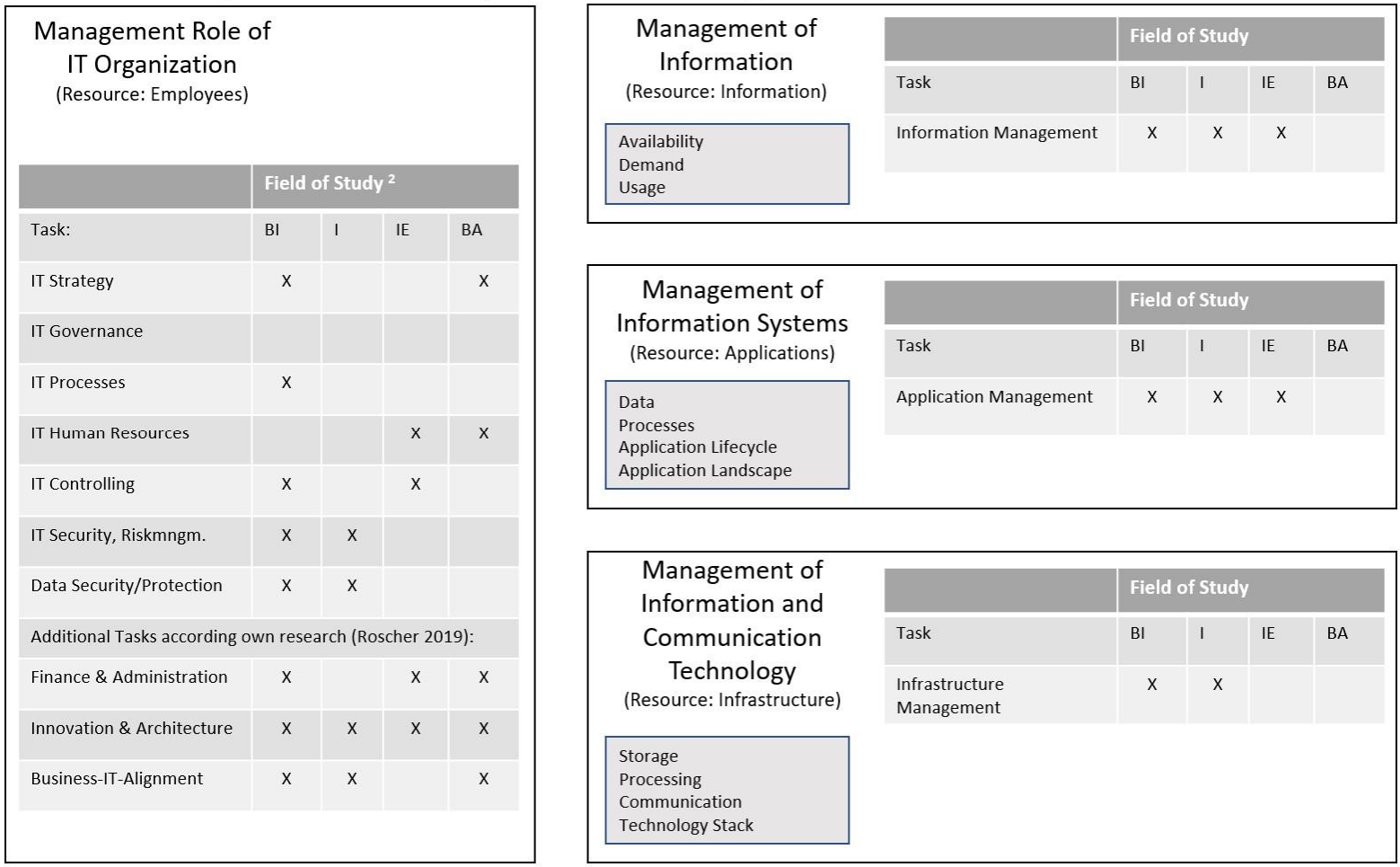

${ }^{1}$ Based on the "FOM Hochschule für Oekonomie \& Management" 03.2020;

${ }^{2}$ BI: Business Informatics; I: Informatics; IE: Industrial Engineering; BA: Business Administration

Fig. 1: Lecture mapping to the tasks of IT Organisations (Krcmar 2015; Roscher and Brink 2020) 


\section{iERBMF}

\subsection{Conclusion and Suggestions}

Individual Knowledge is the product of education and training. In the area of IT Management several different types of knowledge are needed to be successful and effective. Besides Political competence which grows with time, two areas of competence can be trained: IT cmpence and business competence (Smaltz et al. 2006). Chen and Wu defined IT Competence as ,...levels of skills/knowledge that enable him or her to configure, implement, apply, and evaluate IT, with the purpose of establishing enterprise- wide IT infrastructure, initiate various sorts of business applications, and integrate IT functions with critical business processes.". While Business competence was described as ,...level of skills/knowledge that enabled them to understand the dominspecific knowledge of business, speak the language of business, and interact with their business partners in other divisions. "(Chen and Wu 2011).

The mapping of studies to the tasks of an IT Organisation suggest that the best fit would be the Business Informatics education as it especially focuses on the management role of IT organisations. Applicants with Informatics studies are missing business relevant knowledge and qualification beginning from Business process management, Business administration, Strategy development, IT Governance, ending at HR skills.

This gap might be filled by experience in management postions or project management positions with several years of service or by additional qualifications aquired in seminars.

In certain cases a Informatics study might be the first choice - especially if the product is closely connected to the business IT Architecture. In one case the job advertisement asked specifically after a CIO with IT Software development due to this reason.

In most other cases organizations should look for candidates with Business and IT knowledge as the requirements of digitization, new business models and Internet of Things (IoT) require diverse qualifications in order to allign Business with IT and support new upcoming demands outside the pure provision of internal IT services.

Hütter and Riedel (Hütter and Riedl 2017) suggest executive management (CEO/CFO) of companies to define the scope of the IT department, then select one or more roles. If the roles selected is Technology provider or Integration advisor, candidates from the field of Informatics or Industrial enginering might be a good fit. For other roles like strategic supporter, business thinker, innovation driver, integration advisor or relationship manager, candidates with an education in Business Informatics might be more apropriate. Candidates with the background as a Business administrator might be a good fit to the role as technology provider as these IT Managers focus mainly on the provision of cost- effective IT Solutions. 


\section{i[ERBMF}

\section{References}

Chan, Y. E.; Sabherwal, R.; Thatcher, J. B. (2006): Antecedents and outcomes of strategic IS alignment. An empirical investigation. IEEE Trans. Eng. Manage. 53 (1), pp. 27-47.

Chen, Yi- Cheng; Wu, Jen- Her (2011): IT management capability and its impact on the performance of a CIO. Information \& Management 48 (4- 5), pp. 145-156.

Durst, Michael (2008): Wertorientiertes Management von IT- Architekturen: Teubner.

FOM Hochschule für Oekonomie: Bachelor of Arts (B.A.) Business Administration. Studieninhalte und - verlauf. Available online at https://www.fom.de/studiengaenge/wirtschaft- und-

management/bachelorstudiengaenge/business- administration/_produkte; inhalte.html, checked on $3 / 3 / 2020$.

FOM Hochschule für Oekonomie: Bachelor of Science (B.Sc.) Informatik. Studieninhalte und verlauf. Available online at https://www.fom.de/studiengaenge/it-

management/bachelorstudiengaenge/informatik/_produkte; inhalte.html, checked on 3/3/2020.

FOM Hochschule für Oekonomie: Bachelor of Science (B.Sc.) Wirtschaftsinformatik.

Studieninhalte und - verlauf. Available online at https://www.fom.de/studiengaenge/itmanagement/bachelor-

studiengang/wirtschaftsinformatik/_produkte; inhalte.html, checked on 3/3/2020.

FOM Hochschule für Oekonomie: Bachelor of Science (B.Sc.) Wirtschaftsingenieurwesen.

Studieninhalte und - verlauf. Available online at

https://www.fom.de/studiengaenge/ingenieurwesen/bachelorstudiengaenge/wirtschaftsingenie urwesen/_produkte;inhalte.html, checked on 3/3/2020.

Hodgkinson, Stephen L. (1992): IT structures for the 1990s: organisation of IT functions in large companies. A survey. Information \& Management 22 (3), pp 161- 175,

Hütter, Alexander; Riedl, René (2017): Chief Information Officer Role Effectiveness. Cham: Springer International Publishing.

Krcmar, Helmut (1991): Integration in der Wirtschaftsinformatik - Aspekte und Tendenzen. In : Integrierte Informationssysteme. Wiesbaden: Gabler Verlag (Schriften zur Unternehmens führung), p. 190.

Krcmar, Helmut (2015): Informationsmanagement. 6., überarb. Aufl. Berlin, Heidelberg: Springer Gabler.

Marrone, Mauricio; Kolbe, Lutz M. (2011): Impact of IT Service Management Frameworks on the IT Organization. Bus Inf Syst Eng 3 (1), pp.5-18.

Peppard, Joe (2010): Unlocking the Performance of the Chief Information Officer (CIO). California Management Review 52 (4), pp. 73-99. 


\section{i[REMF}

Roscher, Bjarne Erik; Brink, Norbert (2020): Tasks of IT managers: Emperical research based on job advertisements in Germany, Submitted for review and presentation for 800th ICEBM, Vienna

Schweda, Christian M.; Schmidt, Werner (2014): Leichtgewichtiges, unternehmensspezifisches IT- Management. HMD 51 (5), pp. 606-615.

Smaltz, D. H.; Sambamurthy, V.; Agarwal, R. (2006): The antecedents of CIO role effectiveness in Organizations. An empirical study in the healthcare sector. IEEE Trans. Eng. Manage. 53 (2), pp. 207-222.

Synnott, William R.; Gruber, William H. (1981): Information resource management. Opportunities and strategies for the 1980s. New York: Wiley.

Szyperski, Norbert; Winand, Udo (1989): Informationsmanagement und informationstechnische Perspektiven. In Knut Bleicher, Eberhard Seidel, Dieter Wagner (Eds.): Organisation. Evolutionäre Interdependenzen von Kultur und Struktur der Unternehmung : Knut Bleicher zum 60. Geburtstag. Wiesbaden: Gabler, pp. 133-150.

Tallon, Paul P. (2014): A Process- Oriented Perspective on the Alignment of Information Technology and Business Strategy. Journal of Management Information Systems 24 (3), pp. 227-268.

Wollnik, M. (1988): Ein Referenzmodell des Informationsmanagements. Information Management 3 (3), pp. 34-43. 